\title{
Investigation of phenolic profiles and antioxidant activities of some Salvia species commonly grown in Southwest Anatolia using UPLC-ESI-MS/MS
}

\author{
Şeyda KIVRAK ${ }^{1 *}$, Tolga GÖKTÜRK², İbrahim KIVRAK ${ }^{2,3}$, Ergun KAYA, Erşan KARABABA ${ }^{1}$
}

\begin{abstract}
Aerial parts of Salvia albimaculata Hedge \& Hub.-Mor., Salvia potentillifolia Boiss \& Heldr. ex Bentham. and Salvia nydeggeri Hub.-Mor. from Soutwest Anatolia, Turkey were evaluated to determine their phenolic compounds and antioxidant properties. According to the ultra performance liquid chromatography with electrospray ionization tandem mass spectrometry (UPLC-ESI-MS/MS) analysis results, caffeic acid $(3582.8 \pm 2.5 \mu \mathrm{g} / \mathrm{g}, 2956.5 \pm 4.6 \mu \mathrm{g} / \mathrm{g}$ and $2457.7 \pm 3.1 \mu \mathrm{g} / \mathrm{g})$ and 3,4-dihydroxy benzoic acid $(1846.2 \pm 3.1 \mu \mathrm{g} / \mathrm{g}, 2019.1 \pm 2.2 \mu \mathrm{g} / \mathrm{g}$ and $1901.3 \pm 1.5 \mu \mathrm{g} / \mathrm{g})$ were found to be in the highest concentrations in S. potentillifolia, S. albimaculata and S. nydeggeri, respectively. Total amounts of phenolics and flavonoids were determined highest in ethyl acetate extracts of samples and varied from $62.4 \pm 0.1$ to $55.4 \pm 0.0 \mu \mathrm{g}$ PEs $/ \mathrm{mg}$ and from $296.8 \pm 1.4$ to $198.4 \pm 1.5 \mu \mathrm{g}$ QEs $/ \mathrm{mg}$, respectively. Antioxidant activity of $S$. potentillifolia was found to be higher than the others for ABTS ${ }^{\cdot+}$ and $\beta$-carotene linoleic acid assays $\left(\mathrm{SC}_{50}=49.8 \pm 0.9\right.$ and $\mathrm{IC}_{50}=26.1 \pm 0.6 \mu \mathrm{g} / \mathrm{mL}$, respectively) while $S$. albimaculata was found to be higher for $\mathrm{DPPH}$ assay $\left(\mathrm{SC}_{50}=227.4 \pm 1.1 \mu \mathrm{g} / \mathrm{mL}\right)$.
\end{abstract}

Keywords: antioxidant activity; phenolics; Salvia albimaculata; Salvia nydeggeri; UPLC-ESI-MS/MS.

Practical Application: The results of this study indicated that Salvia species possess a potential source of phenolics, antioxidants, nutrients and those may be used in food, pharmaceutical and cosmetic industries as a natural antioxidant. To the best of our knowledge, this is the first report on the determination of individual phenolic profiles of S. potentillifolia, S. albimaculata and S. nydeggeri with high accuracy and precision owing to high throughput instrument UPLC-ESI-MS/MS and sample analysis technique. Natural antioxidants are used as preservatives in many industries, especially in food and cosmetic industries. Therefore, the need for new and safer antioxidant sources is still maintained and may be compensated by the studied Salvia species. Thus scientists and manufacturers may benefit from the valuable properties of S. potentillifolia, S. albimaculata and S. nydeggeri.

\section{Introduction}

The genus Salvia is the largest member of the Lamiaceae family with nearly 1000 species spread throughout the various regions of the World mainly central and south America, western Asia (especially Turkey, Iran, Russia) and eastern Asia. Recently, 99 species of the genus Salvia have been identified in Turkey and 52 (52\%) of them are endemic to Turkey (Alziar, 1988; Celep et al., 2014). Some members of the Salvia genus are commercially important and used for flavouring agents in foods as well as cosmetics, perfumery and the pharmaceutical industries with its biological activities (Chalchat et al., 1998; Villa et al., 2009).

The traditional medical practices of the Salvia species have been studied all over the world (Martínez-Francés et al., 2017; Li et al., 2013). It is known that Salvia species have been used as infusions against simple diseases in Anatolian traditional medicine applications (Baytop, 1999). Many Salvia species have been reported for use in the treatment of diseases such as epilepsy, colds, bronchitis and tuberculosis (Dweck, 2000) as well as biological activities such as antioxidant, antimicrobial (Kelen \& Tepe, 2008), anti-inflammatory (González-Chávez et al., 2017), antidiabetic (Eidi \& Eidi, 2009), antitumor (Fiore et al., 2012), anti cancer (Jiang et al., 2017) ve antiviral activities (Šmidling et al., 2008). Additionally, Scholey et al. (2008) examined the administration of a standardised Salvia extract to improve cognitive function in healthy older individuals and reported enhancement in cognative performance. Recently, Lopresti (2017) published a useful review about potential cognitive-enhancing and protective effects of Salvia and Miroddi et al. (2014) has reviewed clinical trials assessing pharmacological properties of Salvia species on memory, cognitive impairment and alzheimer's disease.

Today, it is well known that free radicals cause many diseases. Antioxidants have great importance in the fight against free radicals, which can damage biological molecules with different mechanisms of action (Young \& Woodside, 2001) and the interest in the usage of antioxidants in the food, pharmaceutical and cosmetic industries is constantly increasing. Nowadays, synthetic antioxidants such as butylated hydroxyanisole (BHA), 
Butylated hydroxytoluene (BHT) and natural antioxidants are used as preservatives in many industries, especially in food industry. However, the concerns about the safety and toxicity of synthetic antioxidants have not been overcome yet (Kahl, 1984; Pokorný, 2007; Ito et al., 1986). Therefore, the need for new and safer antioxidant sources is still maintained.

As one of the plants used as natural antioxidant source is the genus Salvia and the antioxidant activities of Salvia extracts have been associated mainly with their total phenolic contents (Farhat et al., 2013; Dudonné et al., 2009). Plants with phenolic content are used especially in oily food because of their significant functions such as dealing with undesirable fragrances, prolonging thier shelf life, delaying the formation of toxic oxidation products, increasing nutritional value and preventing microbial growth. (Tepe et al., 2006; Karpinska et al., 2001; Rota et al., 2004). Phenolic compounds are known to be extremely beneficial in terms of human nutrition (Ou \& Kwok, 2004), cosmetic (Magnani et al., 2014) and pharmacological (Galati \& O’Brien, 2004).

A wide variety of Salvia species have been studied as novel phenolic compound sources and qualitative and quantitative analyzes of phenolic compounds have been carried out using various techniques. (Orhan et al., 2012; Kamatou et al., 2010; $\mathrm{Lu} \& \mathrm{Foo}, 2002)$. It is known that the phenolic compositions and antioxidant activities of Salvia species vary depend on species. For example, Şenol et al. (2010) have examined the radical-scavenging activities of 55 Salvia species include S. nydeggeri using DPPH ${ }^{\circ}$ and FRAP assays and found S. fruticosa and S. cilicica as most active species while Asadi et al. (2010) reported S. hydrange had higher FRAP (ferric reducing antioxidant power) activity than S. lachnocalyx. A number of studies have been done to determine antioxidant activities and phenolic contents of Salvia species (Erdemoglu et al., 2006; Tosun et al., 2009; Akkol et al., 2008; Alimpić et al., 2017). To the best of our knowledge, there is no any study on determination of phenolic profile of S. nydeggeri, S. albimaculata and S. potentilifolia using UPLC-MS/MS.

In this study, phenolic profiles of three edible and commercially valuable Salvia species were analyzed using UPLC-ESI-MS/MS with new extractions techniques. Quantitative determinations were made using calibration curves. Total phenolic and flavonoid concentrations were determined for each plant. The antioxidant activity of plant extracts was determined using three complimentary methods ( $\beta$-carotene-linoleic acid bleaching, DPPH ${ }^{*}$ free radical scavenging and $\mathrm{ABTS}^{+}$cation radical scavenging). Correlations between phenolic and flavonoid content and antioxidant activity results were determined.

\section{Materials and methods}

\subsection{Chemicals and reagents}

All Phenolic standards purchased from Sigma-Aldrich Chemie $\mathrm{GmbH}$ (Steinheim, Germany). Quercetin, pyrocatechol, $\beta$-carotene, linoleic acid, polyoxyethylene sorbitan monopalmitate (Tween-40), Folin-Ciocalteu's reagent (FCR), potassium acetate, butylated hydroxytoluene (BHT), 1,1-diphenyl-2-picrylhydrazyl (DPPH*) were obtained from Sigma Chemical Co. (Sigma-Aldrich $\mathrm{GmbH}$, Steinheim, Germany). 2,2'-Azinobis(3-ethylbenzothiazoline6-sulfonic acid) (ABTS) diammonium salt was obtained from Fluka Chemie (Fluka Chemie GmbH, Steinheim, Germany). All solvents and other chemicals were of analytical grade purity and were supplied from Merck KGaA (Darmstadt, Germany). HPLC-grade water $(18.2 \mathrm{~m} \Omega)$ was purified using a Milipore Elix Advantage 10 and Milli-Q Advantage A10 (Molsheim, France) system that comprise reverse osmosis, ion exchange, and filtration steps.

\subsection{Plant materials}

Salvia albimaculata Hedge \& Hub.-Mor. samples were collected in the region between Burdur, 15. km from Tefenni to Sögüt, Turkey. Salvia potentillifolia Boiss. \& Heldr. ex Bentham. samples were collected in the region between Burdur, $15 . \mathrm{km}$ from Gölhisar to Altınyayla, Turkey and Salvia nydeggeri Hub.-Mor. samples were collected in the region between Muğla-Fethiye, 8 . and $9 . \mathrm{km}$ from Fethiye to Antalya, Turkey. All Salvia species were endemic to their region and collected in August, 2015. Samples were dried under shadow in ambient temperature $\left(25^{\circ} \mathrm{C}\right)$ for the extraction procedures. Authentication of the plant materials were performed by Dr. Ergun Kaya from Department of Molecular Biology and Genetics, Faculty of Science, Muğla Sitkı Koçman University, Muğla (Turkey).

\subsection{Extraction of Salvia species}

In the determination of total phenolic content, total flavonoid content and antioxidant activities of Salvia species, methanol, hexane, ethyl acetate and water extracts were used. The Salvia samples were extracted five times for $24 \mathrm{~h}$ at room temperature with methanol, filtered through Whatman no 4 and solvents were evaporated (Heidolph, Hei-VAP Precision). Then dry plant extracts were dissolved in distilled water and subjected to liquid-liquid extraction with hexane and ethly acetate, respectively. For each plant, hexane and ethyl acetate extracts were evaporated to dryness under vacuum. The plants remaining after extraction with methanol were used for the water extraction. For this purpose, the plants remaining were extracted with water at $80^{\circ} \mathrm{C}$, filtered through Whatman no 4 and the water extracts were lyophilized (Christ Freeze Dryer, Alpha 1-4 LD plus, Germany). All extracts were stored in deepfreeze $\left(-18^{\circ} \mathrm{C}\right)$ for further analysis.

\subsection{Determination of total phenolic and flavonoid concentration}

The total concentrations of phenolic content of extracts were determined using the Folin-Ciocalteu Reagent (FCR) according to the method described by (Slinkard \& Singleton, 1977; Singleton et al., 1999) and results expressed as microgrammes of pyrocatechol equivalents (PEs). Briefly, the sample solution $(1 \mathrm{~mL})$ dissolved in methanol was added to distilled water $(46 \mathrm{~mL})$ and mixed with FCR (1 mL). After $3 \mathrm{~min}, 3 \mathrm{ml}$ of $\mathrm{Na}_{2} \mathrm{CO}_{3}(2 \%)$ was added to the mixture and this mixture was kept in room temperature for $2 \mathrm{~h}$ by shaken intermittently. The absorbance was 
read at $760 \mathrm{~nm}$. The concentration of total phenolic compounds was calculated according to the following equation (Equation 1) that was obtained from the standard pyrocatechol graph:

Absorbance $=0.0073 . x(\mu g)$ Pyrocatechol $-0.1665 ; r^{2}=0.9976$

Quantification of total flavonoid concentrations of the extracts were determined as the aluminum nitrate method described by Moreno et al. (2000) as quercetin equivalents (QEs). $1 \mathrm{~mL}$ of solution containin $1 \mathrm{mg}$ of sample in ethanol was mixed with $10 \%$ aluminum nitrate $(100 \mu \mathrm{L})$ followed by $1 \mathrm{M}$ potassium acetate $(100 \mu \mathrm{L})$, and $80 \%$ ethanol $(3.8 \mathrm{~mL})$ in test tubes. Mixtures were kept in room temperature for $40 \mathrm{~min}$ and then absorbance was measured at $415 \mathrm{~nm}$. The total concentrations of flavonoid contents were calculated according to the following equation (Equation 2) that was obtained from the standard quercetin graph:

Absorbance $=0.0082 . x(\mu g)$ Quercetin $+0.0073 ; r^{2}=0.9998$

\subsection{Antioxidant activity of the extracts}

\section{$\beta$-Carotene-Linoleic Acid Bleaching Assay}

The total antioxidant activity was determined using $\beta$-carotene-linoleic acid assay based on the detection of inhibition of conjugated dien hydroperoxides due to oxidation of linoleic acid (Miller, 1971). This method uses the bleaching of $\beta$-carotene. Briefly, $\beta$-carotene $(0.5 \mathrm{mg})$ was dissolved in $1 \mathrm{~mL}$ of chloroform. Tween $40(200 \mathrm{mg})$ and linoleic acid $(20 \mu \mathrm{L})$ were added to this mixure. Chloroform was completely evaporated using a vacuum evaporator. Then, $100 \mathrm{~mL}$ of distilled water, saturated with oxygen, was added by vigorous shaking. $4 \mathrm{~mL}$ of this emulsion was mixed with $1 \mathrm{~mL}$ extract solutions at different concentrations ranging $500 \mu \mathrm{g}$ to $4000 \mu \mathrm{g}$. Zero time absorbances were measured at $470 \mathrm{~nm}$ just after emulsions were transfered to each tube. $1 \mathrm{~mL}$ of methanol was used as control. The emulsion systems were incubated at $50{ }^{\circ} \mathrm{C}$ untill the color of $\beta$-carotene was disappeared after $120 \mathrm{~min}$. The results were given as $50 \%$ inhibition concentration $\left(\mathrm{IC}_{50}\right)$.

\section{$D P P H \cdot$ Free Radical Scavenging Assay}

The free radical scavenging activities of plant extracts were determined using DPPH (2,2-Diphenyl-1-picrylhydrazyl) free radical assay (Blois, 1958) with slight modifications. Briefly, $4 \mathrm{~mL}$ of $0.004 \% \mathrm{DPPH}^{*}$ solution in ethanol was added to the extract solutions $(1 \mathrm{~mL})$ at concentrations ranging from $500 \mu \mathrm{g}$ to $4000 \mu \mathrm{g} .1 \mathrm{~mL}$ of ethanol was used as a control. After $30 \mathrm{~min}$ of incubation at room temperature, the absorbance was measured at $517 \mathrm{~nm}$. Absorbance values of the samples were evaluated against the control. The free radical scavenging activity (RSA) was calculated using the following equation (Equation 3):

DPPH RSA $(\%$ inhibition $)=\left[\left(A_{\text {Control }}-A_{\text {Sample }}\right) / A_{\text {Control }}\right] \times 100$

Where $\mathrm{A}_{\text {Sample }}$ is the absorbance of the solution containing the sample and $\mathrm{A}_{\text {Control }}$ is the absorbance of the $\mathrm{DPPH}^{\bullet}$ solution.

\section{ABTS ${ }^{\bullet+}$ Cation Radical Decolorization Assay}

The cation radical scavenging activities of the extracts were determined using ABTS (2,2-azinobis (3-ethylbenzothiazoline6-sulfonic acid) diammonium salt) (Re et al., 1999). Briefly, $7 \mathrm{mM} \mathrm{ABTS}$ in water and $2.45 \mathrm{mM} \mathrm{K}_{2} \mathrm{SO}_{8}$ reacted to form $5 \mathrm{~mL}$ of $\mathrm{ABTS}^{-+}$radical. The mixture was stored in the dark at room temperature for $16 \mathrm{~h}$ to allow cation radical formation. $1 \mathrm{~mL}$ of this radical solution was adjusted by diluting with ethanol to give an absorbance about 0.700 . Then $4 \mathrm{~mL}$ of the ethanol-prepared ABTS $^{*+}$ solution was added onto $1 \mathrm{~mL}$ of the sample at concentrations ranging from $500 \mu \mathrm{g}$ to $4000 \mu \mathrm{g}$. Ethanol $(1 \mathrm{~mL})$ was used as control. After incubation at room temperature for $10 \mathrm{~min}$, the absorbance was measured at $734 \mathrm{~nm}$. Absorbance values of the samples were evaluated against the control. ABTS $^{*+}$ cation radical removal activity was calculated using the following equation (Equation 4):

$$
\text { ABTS }^{\circ+} R S A \%=\left[\left(A_{\text {Control }}-A_{\text {Sample }}\right) / A_{\text {Control }}\right] \times 100
$$

Where $\mathrm{A}_{\text {Sample }}$ is the absorbance of remaining concentration of $\mathrm{ABTS}^{\cdot+}$ in the presence of sample and $\mathrm{A}_{\text {Control }}$ is the initial concentration of the ABTS ${ }^{\bullet+}$.

\subsection{Determination of phenolic compounds using UPLC-ESI-MS/MS}

Phenolic compounds of plant samples were analyzed using high-throughput instrument, a Waters UPLC-ESI-MS/MS and C18 column (Acquity UPLC BEH C18 $100 \mathrm{~mm} \times 2.1 \mathrm{~mm}$, 1.7- $\mu \mathrm{m}$ particle size) and the separation of phenolic compounds was performed by gradient elution at $40{ }^{\circ} \mathrm{C}$. The mobile phases were composed of solvent A (0.5\% acetic acid in water) and solvent B ( $0.5 \%$ acetic acid in methanol), and the flow rate was $0.650 \mathrm{~mL} / \mathrm{min}$.

Approximately $20 \mathrm{~g}$ of each plant sample was frozen with $200 \mathrm{~mL}$ of liquid nitrogen and then lyophlized. A mixture of $30 \mathrm{~mL}$ of acetone:water (80:20) was added to lyophlized powder and the mixture was allowed to extraction for $6 \mathrm{~h}$ at $-86^{\circ} \mathrm{C}$. Then, ultrasonic extraction was applied for $15 \mathrm{~min}$., the extract was centrifuged at $4000 \mathrm{rpm}$ for $10 \mathrm{~min}$ at $20^{\circ} \mathrm{C}$ and filtered using Whatman No 4. The residue was extracted twice more with $30 \mathrm{~mL}$ of acetone:water mixtures (Kivrak et al., 2013, 2017; Kıvrak \& Kıvrak, 2016; Kıvrak, 2015), extracts were combined, the solvents in the combined extracts was evaporated at $40^{\circ} \mathrm{C}$ (Rotary Evaporator Heidolph Basis Hei-VAP ML). The aqueous phase was washed 3 times with $30 \mathrm{~mL}$ of $\mathrm{n}$-hexane and 3 times with $30 \mathrm{~mL}$ of ethyl acetate for liquid-liquid extraction. The organic phases were combined and evaporated to dryness at $40^{\circ} \mathrm{C}$. The residue was redissolved in a mixture of water:methanol (80:20). The solution $(2 \mu \mathrm{L})$ was passed through Macherey-Nagel Chromafil Xtra PTFE-20/25 0.20 $\mu \mathrm{m}$ filters and injected to UPLC-ESI-MS/MS (Waters Acquity Ultra Performance LC, Xevo TQ-S MS-MS). In this present study, method parameters of UPLC-ESI-MS/MS for the phenolic compounds analysis were applied according to our previous literatures (Kıvrak et al., 2013, 2017; Kıvrak \& Kıvrak, 2016; Kıvrak, 2015) (Table 1). All extractions techniques and UPLC-ESI-MS/MS analysis methods used in the analysis of phenolic compounds are original. 
Table 1. Method parameters for the phenolic compounds analysis using UPLC-ESI-MS/MS.

\begin{tabular}{|c|c|c|c|c|c|}
\hline No & Compounds & $\begin{array}{c}\text { Quantification }>\text { confirmatory } \\
\text { transition }(\mathrm{m} / \mathrm{z})\end{array}$ & $\begin{array}{l}\text { Cone voltage } \\
\text { (V) }\end{array}$ & $\begin{array}{l}\text { Collision } \\
\text { energy }(\mathrm{V})\end{array}$ & $\begin{array}{l}\text { Retention time } \\
(\text { min) }\end{array}$ \\
\hline 1 & Pyrogallol & $125.01>69.10,79.04,81.02$ & 20 & $17,17,14$ & 0.97 \\
\hline 2 & Gallic acid & $168.95>125.02,107.02,97.02$ & 20 & $25,20,14$ & 1.10 \\
\hline 4 & 3,4-dihydroxy benzoic acid & $153.06>108.00,81.01,91.01$ & 10 & $20,25,20$ & 1.86 \\
\hline 5 & Gentisic acid & $153.05>109.04,108.03,81.00$ & 10 & $20,20,12$ & 1.86 \\
\hline 8 & 4-Hydroxy benzoic acid & $136.98>93.03,65.10$ & 10 & 25,14 & 2.75 \\
\hline 9 & 3,4-Dihydroxybenzaldehyde & $137.00>91.93,107.94,136.00$ & 8 & $21,20,18$ & 2.76 \\
\hline 10 & Catechin hydrate & $288.88>109.15,124.99,245.26$ & 30 & $25,20,15$ & 3.45 \\
\hline 11 & Vanillic acid & $166.98>151.97,108.03,123.03$ & 20 & $18,12,14$ & 3.61 \\
\hline 12 & Caffeic acid & $179.10>135.14,107.10,133.9$ & 32 & $23,23,24$ & 3.67 \\
\hline 16 & Ferulic acid & $193.03>134.06,178.00,149.02$ & 20 & $16,12,13$ & 5.36 \\
\hline 17 & Epicatechin & $189.18>151.00,203.00,205.00$ & 20 & $20,20,20$ & 5.50 \\
\hline 18 & Chlorogenic acid & $353.02>191.01,179.09,161.02$ & 30 & $30,28,24$ & 5.52 \\
\hline 19 & Catechin gallate & $441.00>168.98,288.97$ & 30 & 20,20 & 5.91 \\
\hline 20 & Rutin & $609.00>254.99,270.93,299.90$ & 17 & $55,55,40$ & 5.95 \\
\hline 21 & trans-2-Hydroxycinnamic acid & $163.04>119.04,117.01,93.07$ & 10 & $25,22,13$ & 6.32 \\
\hline 22 & Myricetin & $316.90>107.07,137.01,150.97$ & 30 & $30,25,25$ & 6.83 \\
\hline 23 & Resveratrol & $227.01>143.01,159.05,185.03$ & 30 & $25,18,18$ & 7.13 \\
\hline 24 & trans-Cinnamic acid & $146.98>103.03,62.18$ & 30 & 10,10 & 8.19 \\
\hline 25 & Luteolin & $284.91>107.01,133.05,151.02$ & 20 & $30,33,30$ & 8.32 \\
\hline 32 & Chrysin & $252.99>63.05,107.05,142.99$ & 20 & $30,25,25$ & 11.06 \\
\hline
\end{tabular}

\section{Results and discussion}

\subsection{Total phenolic and flavonoid concentrations}

Methanol, hexane, ethyl acetate and water extracts of Salvia species were examined for the determination of total phenolic and flavonoid contents. The results expressed as pyrocatechol and quercetin equivalents, respectively (Table 2). According to the study, ethyl acetate extract of $S$. albimaculata showed the highest amount of total flavonoid content $(296.8 \pm 1.4 \mu \mathrm{g}$ QEs/mg) and the lowest content $(29.1 \pm 0.7 \mu \mathrm{g}$ QEs/mg $)$ of total flavonoid were found belonging to hexane extract of $S$. nydeggeri.

On the other hand, total phenolic content analysis of Salvia species revealed that ethyl acetate extract of $S$. potentillifolia had the highest concentration $(62.4 \pm 0.1 \mu \mathrm{g}$ PEs/mg) of total phenolics among all extracts and species while the water extract of $S$. nydeggeri had the lowest amount $(36.3 \pm 0.8 \mu \mathrm{g}$ PEs $/ \mathrm{mg})$ of total phenolic content. For all species, the results indicated that ethyl acetate extracts had the highest total phenolic and
Table 2. Total phenolic and flavonoid concentrations of Salvia samples.

\begin{tabular}{cccc}
\hline \multirow{5}{*}{ Extracts } & & $\begin{array}{c}\text { Total Phenolic } \\
\text { Content } \\
(\mu \mathrm{g} \text { PEs } / \mathrm{mg} \text { of } \\
\text { extact })\end{array}$ & $\begin{array}{c}\text { Total Flavonoid } \\
\text { Content } \\
(\mu \mathrm{g} \text { QEs } / \mathrm{mg} \text { of } \\
\text { extract })\end{array}$ \\
\hline \multirow{2}{*}{ S. albimaculata } & Methanol & $52.3 \pm 0.5$ & $158.4 \pm 1.0$ \\
& Hexane & $41.3 \pm 0.6$ & $32.3 \pm 0.7$ \\
& Ethyl acetate & $56.3 \pm 0.0$ & $296.8 \pm 1.4$ \\
& Water & $36.4 \pm 0.5$ & $88.1 \pm 1.0$ \\
S. potentillifolia nydeggeri & Methanol & $53.2 \pm 0.4$ & $168.5 \pm 1.0$ \\
& Hexane & $49.2 \pm 1.1$ & $35.1 \pm 0.7$ \\
& Ethyl acetate & $62.4 \pm 0.1$ & $292.2 \pm 1.1$ \\
& Water & $46.0 \pm 1.3$ & $118.5 \pm 0.9$ \\
& Methanol & $46.1 \pm 0.5$ & $136.0 \pm 1.2$ \\
& Hexane & $41.1 \pm 1.0$ & $29.1 \pm 0.7$ \\
& Ethyl acetate & $55.4 \pm 0.0$ & $198.4 \pm 1.5$ \\
& Water & $36.3 \pm 0.8$ & $99.1 \pm 0.9$ \\
\hline
\end{tabular}

The values were given as averages of 3 parallel measurements $p<0.05$. 
flavonoid content while the lowest amounts of total phenolics and flavonoids determined in water extracts and hexane extracts, respectively.

\subsection{Individual phenolic compounds}

In this study, individual phenolic compounds of three Salvia species were determined using UPLC-ESI-MS/MS. Thirty two of phenolic compounds were identified and 21 of them were detected and quantitated in all Salvia samples. Pyrogallol, galantamin, catechin hydrate, epicatechin, catechin gallate, trans-2-hydroxycinnamic acid, myricetin, resveratrol, quercetin, chlorogenic acid and gallic acid were not detected. All results were summarized in Table 3 and total ion chromatograms (TIC) of most abundant phenolic compunds of Salvia species were given in Figure 1.

The major phenolic compounds revealed for all Salvia species as caffeic acid and 3,4-dihydroxy benzoic acid. On the other hand, gentisic acid, syringic acid and 4-hydroxy benzoic acid were also quite high. A significant component, caffeic acid, was indicated highest amount in S. potentillifolia $(3582.8 \pm 2.5 \mu \mathrm{g} / \mathrm{g})$ compared to the other Salvia species S. albimaculata $(2956.5 \pm 4.6 \mu \mathrm{g} / \mathrm{g})$ and $S$. nydeggeri $(2457.7 \pm 3.1 \mu \mathrm{g} / \mathrm{g})$ evaluated in this study. Caffeic acid contents of various Salvia species were previously investigated using different methods. For example, Farhat et al. (2013) reported that caffeic acid was detected in methanolic extracts of S. officinalis, S. verbenaca, S. argentea and S. aegyptica as $236.5 \pm 4.8,90.5 \pm 0.5,62.5 \pm 0.2$ and $117.6 \pm 2.7 \mu \mathrm{g} / \mathrm{g}$ of dry plant material weight, respectively. In other report, caffeic acid values were determined as $15.6 \pm 0.9$ and $4.8 \pm 0.4 \mathrm{mg} / \mathrm{kg}$ for ethyl acetate extracts of $S$. halophila and $S$. virgata, respectively (Akkol et al., 2008). These results indicates that phenolic content of Salvia species may change depends on location, season, origin of plant or investigation method as previously reported by other researchers too (Alimpić et al., 2017). The second major phenolic compound 3,4-dihydroxybenzoic acid was found to be highest in S. albimaculata $(2019.1 \pm 2.2 \mu \mathrm{g} / \mathrm{g})$ followed by $S$. nydeggeri $(1901.3 \pm 1.5 \mu \mathrm{g} / \mathrm{g})$ and $S$. potentilifolia $(1846.2 \pm 3.1 \mu \mathrm{g} / \mathrm{g})$.

Table 3. Phenolic content ( $\mu \mathrm{g} / \mathrm{g}$ dry weight \pm standard deviation) of Salvia species.

\begin{tabular}{|c|c|c|c|c|c|}
\hline No & Compounds & Retention time (min) & S. potentillifolia & S. nydeggeri & S. albimaculata \\
\hline 1 & Pyrogallol & 0.97 & nd & nd & nd \\
\hline 2 & Gallic acid & 1.10 & nd & nd & nd \\
\hline 3 & Homogentisic acid & 1.47 & $690.1 \pm 1.2$ & $100.2 \pm 0.9$ & $550.3 \pm 1.7$ \\
\hline 4 & 3,4-dihydroxy benzoic acid & 1.86 & $1846.4 \pm 3.1$ & $1901.3 \pm 1.5$ & $2019.1 \pm 2.2$ \\
\hline 5 & Gentisic acid & 1.86 & $1240.2 \pm 1.3$ & $1236.7 \pm 2.9$ & $1201.1 \pm 1.5$ \\
\hline 6 & Pyrocatechol & 2.38 & $294.8 \pm 1.1$ & $251.4 \pm 0.7$ & $198.5 \pm 0.8$ \\
\hline 7 & Galantamin & 2.68 & nd & nd & nd \\
\hline 8 & 4-Hydroxy benzoic acid & 2.75 & $1126.9 \pm 2.3$ & $998.5 \pm 1.3$ & $1236.5 \pm 2.5$ \\
\hline 9 & 3,4-Dihydroxybenzaldehyde & 2.76 & $996.9 \pm 0.7$ & $1047.6 \pm 1.5$ & $1006.1 \pm 3.3$ \\
\hline 10 & Catechin hydrate & 3.45 & nd & nd & nd \\
\hline 11 & Vanillic acid & 3.61 & $927.5 \pm 1.1$ & $1021.5 \pm 2.2$ & $999.5 \pm 1.2$ \\
\hline 12 & Caffeic acid & 3.67 & $3582.8 \pm 2.5$ & $2457.7 \pm 3.1$ & $2956.5 \pm 4.6$ \\
\hline 13 & Syringic acid & 4.11 & $1322.1 \pm 3.3$ & $963.6 \pm 2.8$ & $1635.7 \pm 3.1$ \\
\hline 14 & Vanillin & 4.51 & $1223.0 \pm 3.1$ & $734.6 \pm 1.0$ & $1146.1 \pm 2.1$ \\
\hline 15 & $p$-Coumaric acid & 4.65 & $312.4 \pm 1.0$ & $214.5 \pm 1.0$ & $424.3 \pm 3.7$ \\
\hline 16 & Ferulic acid & 5.36 & $981.0 \pm 2.1$ & $1002.5 \pm 1.9$ & $1057.1 \pm 2.3$ \\
\hline 17 & Epicatechin & 5.50 & nd & nd & nd \\
\hline 18 & Chlorogenic acid & 5.52 & nd & nd & nd \\
\hline 19 & Catechin gallate & 5.91 & nd & nd & nd \\
\hline 20 & Rutin & 5.95 & $266.8 \pm 2.3$ & $254.4 \pm 1.6$ & $199.1 \pm 0.9$ \\
\hline 21 & trans-2-Hydroxycinnamic acid & 6.32 & nd & nd & nd \\
\hline 22 & Myricetin & 6.83 & nd & nd & nd \\
\hline 23 & Resveratrol & 7.23 & nd & nd & nd \\
\hline 24 & trans-Cinnamic acid & 8.19 & $10.3 \pm 0.9$ & $12.9 \pm 0.7$ & $14.7 \pm 1.0$ \\
\hline 25 & Luteolin & 8.32 & $857.0 \pm 3.6$ & $1101.5 \pm 2.0$ & $953.0 \pm 2.2$ \\
\hline 26 & Quercetin & 8.29 & nd & nd & nd \\
\hline 27 & Naringenin & 9.17 & $11.1 \pm 1.0$ & $15.4 \pm 1.3$ & $12.1 \pm 0.9$ \\
\hline 28 & Genistein & 9.22 & $160.1 \pm 0.1$ & $99.1 \pm 0.1$ & $178.1 \pm 0.2$ \\
\hline 29 & Apigenin & 9.35 & $171.1 \pm 1.0$ & $151.3 \pm 0.9$ & $182.0 \pm 1.2$ \\
\hline 30 & Kaempferol & 9.50 & $941.3 \pm 2.5$ & $1121.9 \pm 4.4$ & $854.6 \pm 2.1$ \\
\hline 31 & Hesperetin & 9.71 & $71.1 \pm 1.2$ & $112.3 \pm 2.6$ & $82.1 \pm 2.5$ \\
\hline 32 & Chrysin & 11.06 & $8.1 \pm 0.5$ & $9.3 \pm 1.0$ & $7.1 \pm 0.5$ \\
\hline
\end{tabular}

nd: not detected. 

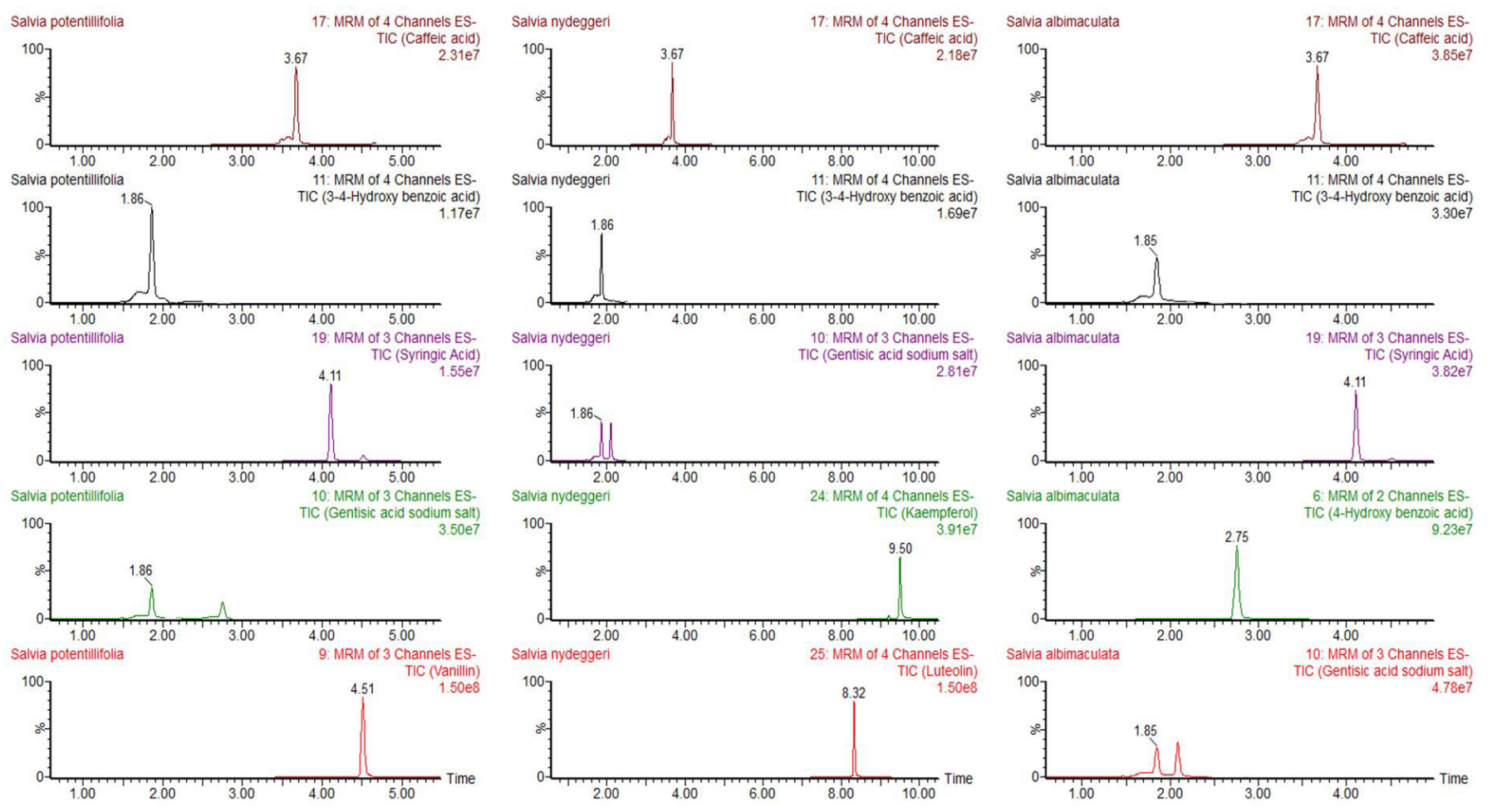

Figure 1. Total ion chromatograms of major phenolic compounds determined in Salvia species.

In the comparision of Salvia species, S. albimaculata was determined richest in syringic acid. The amount of syringic acid determined for $S$. albimaculata $(1635.7 \pm 3.1 \mu \mathrm{g} / \mathrm{g})$ and S. potentillifolia $(1322.1 \pm 3.3 \mu \mathrm{g} / \mathrm{g}$ ) was distincly higher than S. nydeggeri $(963.6 \pm 2.8 \mu \mathrm{g} / \mathrm{g})$.

\subsection{Antioxidant activity}

The antioxidant activity of plant extracts was determined using three complimentary methods ( $\beta$-carotene-linoleic acid bleaching, $\mathrm{DPPH}^{\cdot}$ free radical scavenging and $\mathrm{ABTS}^{*+}$ cation radical scavenging). According to the total phenolic and flavonoid determination results, the ethyl acetate extracts were presented higher total phenolic and flavonoid content in all species. With this reason, ethyl acetate fractions of Salvia extracts were choosen for comparision of antioxidant activities instead of methanol, water and hexane extracts. Antioxidant activity values were examined and the $50 \%$ inhibition concentration $\left(\mathrm{IC}_{50}\right)$ of ethyl acetate extract was found to be highest as $26.1 \pm 0.6 \mu \mathrm{g} / \mathrm{mL}$ for S. potentillifolia in the $\beta$-carotene-linoleic acid method. The antioxidant activities of the Salvia species and standartds were decreased in the following order: S. potentillifolia $>$ S. albimaculata $>$ BHA $>$ S. nydeggeri $>$ BHT $>\alpha$-Tocopherol. The total antioxidant activity results consistent with total phenolic content results (S. potentillifolia $>$ S. albimaculata $>$ S. nydeggeri). Increased concentrations in all samples also indicate increased inhibition.

In DPPH $\cdot$ assay, none of the species showed better antioxidant activity than standards BHA, BHT or $\alpha$-Tocopherol but highest antioxidant activity was observed in the S. albimaculata extract $(227.4 \pm 1.1 \mu \mathrm{g} / \mathrm{mL})$ and a lower antioxidant activity values were
Table 4. Antioxidant activities of ethyl acetate extracts of Salvia samples.

\begin{tabular}{cccc}
\hline $\begin{array}{c}\text { Extracts/ } \\
\text { Standards }\end{array}$ & $\begin{array}{c}\beta \text {-Carotene- } \\
\text { linoleic acid } \\
\mathrm{IC}_{50}(\mu \mathrm{g} / \mathrm{mL})\end{array}$ & $\begin{array}{c}\mathrm{DPPH} \cdot \\
\mathrm{SC}_{50}(\mu \mathrm{g} / \mathrm{mL})\end{array}$ & $\begin{array}{c}\mathrm{ABTS}^{*+} \\
\mathrm{SC}_{50}(\mu \mathrm{g} / \mathrm{mL})\end{array}$ \\
\hline S. albimaculata & $29.3 \pm 1.2$ & $227.4 \pm 1.1$ & $50.2 \pm 1.0$ \\
S. potentillifolia & $26.1 \pm 0.6$ & $248.4 \pm 2.2$ & $49.8 \pm 0.9$ \\
S. nydeggeri & $32.6 \pm 1.4$ & $312.6 \pm 0.7$ & $52.3 \pm 1.0$ \\
BHA & $32.3 \pm 1.2$ & $168.5 \pm 0.8$ & $20.6 \pm 0.9$ \\
BHT & $34.3 \pm 1.0$ & $155.4 \pm 0.6$ & $28.6 \pm 0.7$ \\
a-Tocopherol & $38.1 \pm 0.7$ & $179.5 \pm 1.3$ & $32.1 \pm 0.6$ \\
\hline
\end{tabular}

$\mathrm{IC}_{50}$ and $\mathrm{SC}_{50}$ values represent the means $\pm \mathrm{SD}$ of three parallel measurements; $\mathrm{BHA}$; Butylated hydroxyanisole, BHT; Butylated hydroxytoluene.

found in S. potentillifolia $(248.4 \pm 2.2 \mu \mathrm{g} / \mathrm{mL})$ and S. nydeggeri $(312.6 \pm 0.7 \mu \mathrm{g} / \mathrm{mL})$. ABTS ${ }^{++}$cation radical scavenging $\mathrm{SC}_{50}$ value of ethyl acetate extract of $S$. potantillifolia was found to be $49.8 \pm 0.9 \mu \mathrm{g} / \mathrm{mL}$ as highest, whereas butylated hydroxyanisole (BHA) $\mathrm{SC}_{50}$ value, used as standard, was $20.6 \pm 0.9 \mu \mathrm{g} / \mathrm{mL}$ (Table 4).

According to the $\beta$-Carotene-linoleic acid and $\mathrm{ABTS}^{\circ+}$ assays, increasing in total phenolic content and antioxidant activity was in positive correlation. These results suggest that the major part of the antioxidant activities in Salvia species selected in this study is a result of the phenolic compounds. This observation has been in accordance with previous literatures, exhibited similar correlations between total phenolic content and antioxidant activity of various plants (Kivrak et al., 2017; Kumar et al., 2014; Mammadov et al., 2012; Piluzza \& Bullitta, 2011). 
In general, the differences between the results obtained in this study and in previous reports is considered to be related by the conditions of experiments, the instrument used and the growing areas and collection times.

\section{Conclusion}

Investigation of phenolic compositions and antioxidant properties of plants or their different extracts revealed remarkable data since the interest on the use of natural sources for food, pharmaceutical and cosmetic industries increased tremendouly in the last decade. In this study, individual phenolic compounds of S. albimaculata, S. nydeggeri and S. potentillifolia were analyzed and quantitated using UPLC for the first time. The studied three Salvia species presented rich phenolic content. In addition, up to now the lack of information about antioxidant activity studies using three complemantry method on S. albimaculata, S. nydeggeri and S. potentillifolia makes this present study unique and important. Considering the results obtained in this study and the large number of researches on Salvia species previously reported, all selected plants have great potential for use in pharmaceutical, cosmetics and many other industrial fields, especially in the food industry. In the light of findings of the present study, particularly remarkable antioxidant activities and rich phenolic contents of plants could trigger the scientists. We also think that the results obtained in this study provide useful of information for researchers who want to study various biological activities of these three Salvia species and encourage entrepreneurs to use them for commercial purposes with the respect of biodiversity conversation.

\section{Acknowledgements}

The authors are grateful to Scientific Research Projects of Muğla Sıtkı Koçman University for financial support of this work (project no: 15/189).

\section{References}

Akkol, E. K., Göger, F., Koşar, M., \& Başer, K. H. C. (2008). Phenolic composition and biological activities of Salvia halophila and Salvia virgata from Turkey. Food Chemistry, 108(3), 942-949. http://dx.doi. org/10.1016/j.foodchem.2007.11.071. PMid:26065756.

Alimpić, A., Knežević, A., Milutinović, M., Stević, T., Šavikin, K., Stajić, M., Marković, S. D., Marin, P., Matevski, V., \& Duletić-Laušević, S. (2017). Biological activities and chemical composition of Salvia amplexicaulis Lam. extracts. Industrial Crops and Products, 105, 1-9. http://dx.doi.org/10.1016/j.indcrop.2017.04.051.

Alziar, G. (1988-1993). Catalogue synonymique des Salvia L. du monde (Lamiaceae) I-VI. Biocosme Mesogéen, 5(3-4), 87-136. 6(1-2, 4): 79-115, 163-204; 7(1-2): 59-109; 9(2-3): 413-497; 10(3-4): 33-117.

Asadi, S., Ahmadiani, A., Esmaeili, M. A., Sonboli, A., Ansari, N., \& Khodagholi, F. (2010). In vitro antioxidant activities and an investigation of neuroprotection by six Salvia species from Iran: A comparative study. Food and Chemical Toxicology, 48(5), 13411349. http://dx.doi.org/10.1016/j.fct.2010.02.035. PMid:20197079.

Baytop, T. (1999). Therapy with medicinal plants in Turkey (past and present) (Istanbul University Publications, no. 3255). Istanbul: Nobel Press House.
Blois, M. S. (1958). Antioxidant determinations by the use of a stable free radical. Nature, 181(4617), 1199-1200. http://dx.doi. org/10.1038/1811199a0.

Celep, F., Kahraman, A., Atalay, Z., \& Doğan, M. (2014). Morphology, anatomy, palynology, mericarp and trichome micromorphology of the rediscovered Turkish endemic Salvia quezelii (Lamiaceae) and their taxonomic implications. Plant Systematics and Evolution, 300(9), 1945-1958. http://dx.doi.org/10.1007/s00606-014-1020-1.

Chalchat, J. C., Michet, A., \& Pasquier, B. (1998). Study of clones of Salvia officinalis L. yields and chemical composition of essential oil. Flavour and Fragrance Journal, 13(1), 68-70. http://dx.doi.org/10.1002/ (SICI)1099-1026(199801/02)13:1<68::AID-FFJ698>3.0.CO;2-8.

Dudonné, S., Vitrac, X., Coutiére, P., Woillez, M., \& Mérillon, J. M. (2009). Comparative study of antioxidant properties and total phenolic content of 30 plant extracts of industrial interest using DPPH, ABTS, FRAP, SOD, and ORAC assays. Journal of Agricultural and Food Chemistry, 57(5), 1768-1774. http://dx.doi.org/10.1021/ jf803011r. PMid:19199445.

Dweck, A. C. (2000). The folklore and cosmetic use of various Salvia species. In S. E. Kintzios (Ed.), Sage: the genus Salvia (pp. 1-25). London: CRC Press.

Eidi, A., \& Eidi, M. (2009). Antidiabetic effects of sage (Salvia officinalis L.) leaves in normal and streptozotocin-induced diabetic rats. Diabetes \& Metabolic Syndrome, 3(1), 40-44. http://dx.doi.org/10.1016/j. dsx.2008.10.007.

Erdemoglu, N., Turan, N. N., Cakõcõ, I., Sener, B., \& Aydõn, A. (2006). Antioxidant activities of some Lamiaceae plant extracts. Phytotherapy Research, 20(1), 9-13. http://dx.doi.org/10.1002/ ptr.1816. PMid:16397914.

Farhat, M. B., Landoulsi, A., Chaouch-Hamada, R., Sotomayor, J. A., \& Jordán, M. J. (2013). Characterization and quantification of phenolic compounds and antioxidant properties of Salvia species growing in different habitats. Industrial Crops and Products, 49, 904-914. http:// dx.doi.org/10.1016/j.indcrop.2013.06.047.

Fiore, G., Massarelli, P., Sajeva, M., \& Franchi, G. (2012). Anti-tumor activity of the methanolic extracts of Salvia menthifolia. Revista Brasileira de Farmacognosia, 22(2), 381-388. http://dx.doi.org/10.1590/ S0102-695X2011005000220.

Galati, G., \& O’Brien, P. J. (2004). Potential toxicity of flavonoids and other dietary phenolics: significance for their chemopreventive and anticancer properties. Free Radical Biology \& Medicine, 37(3), 287-303. http://dx.doi.org/10.1016/j.freeradbiomed.2004.04.034. PMid:15223063.

González-Chávez, M. M., Ramos-Velázquez, C. S., Serrano-Vega, R., Pérez-González, C., Sánchez-Mendoza, E., \& Pérez-Gutiérrez, S. (2017). Anti-inflammatory activity of standardized dichloromethane extract of Salvia connivens on macrophages stimulated by LPS. Pharmaceutical Biology, 55(1), 1467-1472. http://dx.doi.org/10.10 80/13880209.2017.1305423. PMid:28347190.

Ito, N., Hirose, M., Fukushima, S., Tsuda, H., Shirai, T., \& Tatematsu, M. (1986). Studies on antioxidants: their carcinogenic and modifying effects on chemical carcinogenesis. Food and Chemical Toxicology, 24(10-11), 1071-1082. http://dx.doi.org/10.1016/0278-6915(86)902917. PMid:3804112.

Jiang, Y., Zhang, L., \& Rupasinghe, H. P. V. (2017). Antiproliferative effects of extracts from Salvia officinalis L. and Saliva miltiorrhiza Bunge on hepatocellular carcinoma cells. Biomedicine and Pharmacotherapy, 85, 57-67.http://dx.doi.org/10.1016/j.biopha.2016.11.113. PMid:27930987.

Kahl, R. (1984). Synthetic antioxidants: biochemical actions and interference with radiation, toxic compounds, chemical mutagens 
and chemical carcinogens. Toxicology, 33(3-4), 185-228. http://dx.doi. org/10.1016/0300-483X(84)90038-6. PMid:6393452.

Kamatou, G. P. P., Viljoen, A. M., \& Steenkamp, P. (2010). Antioxidant, antiinflammatory activities and HPLC analysis of South African Salvia species. Food Chemistry, 119(2), 684-688. http://dx.doi. org/10.1016/j.foodchem.2009.07.010.

Karpinska, M., Borowski, J., \& Danowska-Oziewicz, M. (2001). The use of natural antioxidants in ready-to-serve food. Food Chemistry, 72(1), 5-9. http://dx.doi.org/10.1016/S0308-8146(00)00171-0.

Kelen, M., \& Tepe, B. (2008). Chemical composition, antioxidant and antimicrobial properties of the essential oils of three Salvia species from Turkish flora. Bioresource Technology, 99(10), 4096-4104. http://dx.doi.org/10.1016/j.biortech.2007.09.002. PMid:17936619.

Kivrak, İ. (2015). Analytical methods applied to assess chemical composition, nutritional value and in vitro bioactivities of Terfezia olbiensis and Terfezia claveryi from Turkey. Food Analytical Methods, 8(5), 1279-1293. http://dx.doi.org/10.1007/s12161-014-0009-2.

Kıvrak, İ., Kıvrak, Ş., Harmandar, M., \& Çetintaş, Y. (2013). Phenolic compounds of pinus brutia ten: chemical investigation and quantitative analysis using an ultra-performance liquid chromatography tandem mass. Records of Natural Products, 7(4), 313-319.

Kıvrak, Ş., \& Kıvrak, İ. (2016). Assessment of phenolic profile of Turkish honeys. International Journal of Food Properties, 20(4), 864-876. http://dx.doi.org/10.1080/10942912.2016.1188307.

Kıvrak, Ş., Göktürk, T., \& Kıvrak, İ. (2017). Assessment of volatile oil composition, phenolics and antioxidant activity of bay (Laurus nobilis) leaf and usage in cosmetic applications. International Journal of Secondary Metabolite, 4(2), 148-161. http://dx.doi.org/10.21448/ ijsm.323800.

Kumar, S., Sandhir, R., \& Ojha, S. (2014). Evaluation of antioxidant activity and total phenol in different varieties of Lantana camara leaves. BMC Research Notes, 7(1), 560. http://dx.doi.org/10.1186/17560500-7-560. PMid:25145266.

Li, M., Li, Q., Zhang, C., Zhang, N., Cui, Z., Huang, L., \& Xiao, P. (2013). An ethnopharmacological investigation of medicinal Salvia plants (Lamiaceae) in China. Acta Pharmaceutica Sinica. B, 3(4), 273-280. http://dx.doi.org/10.1016/j.apsb.2013.06.001.

Lopresti, A. L. (2017). Salvia (Sage): a review of its potential cognitiveenhancing and protective effects. Drugs in R\&D., 17(1), 53-64. http:// dx.doi.org/10.1007/s40268-016-0157-5. PMid:27888449.

Lu, Y., \& Foo, L. Y. (2002). Polyphenolics of Salvia - a review. Phytochemistry, 59(2), 117-140. http://dx.doi.org/10.1016/S00319422(01)00415-0. PMid:11809447.

Magnani, C., Isaac, V. L. B., Correa, M., \& Salgado, H. R. N. (2014). Caffeic acid: a review of its potential use in medications and cosmetics. Analytical Methods, 6(10), 3203-3210. http://dx.doi. org/10.1039/C3AY41807C.

Mammadov, R., Ili, P., \& Dusen, O. (2012). Phenolic contents and antioxidant properties of Muscari parviflorum Desf. Journal of the Chemical Society of Pakistan, 34(3), 651-655.

Martínez-Francés, V., Hahn, E., Ríos, S., Rivera, D., Reich, E., Vila, R., \& Cañigueral, S. (2017). Ethnopharmacological and chemical characterization of Salvia species used in valencian traditional herbal preparations. Frontiers in Pharmacology, 8, 467. http://dx.doi. org/10.3389/fphar.2017.00467. PMid:28790914.

Miller, H. E. (1971). A simplified method for the evaluation of antioxidants. Journal of the American Oil Chemists' Society, 48(2), 1-91. http://dx.doi.org/10.1007/BF02635693.

Miroddi, M., Navarra, M., Quattropani, M. C., Calapai, F., Gangemi, S., \& Calapai, G. (2014). Systematic review of clinical trials assessing pharmacological properties of Salvia species on memory, cognitive impairment and alzheimer's disease. CNS Neuroscience \& Therapeutics, 20(6), 485-495. http://dx.doi.org/10.1111/cns.12270. PMid:24836739.

Moreno, M. I. N., Isla, M. I., Sampietro, A. R., \& Vattuone, M. A. (2000). Comparison of the free radical-scavenging activity of propolis from several regions of Argentina. Journal of Ethnopharmacology, 71(1-2), 109-114. http://dx.doi.org/10.1016/S0378-8741(99)001890. PMid:10904153.

Orhan, I. E., Senol, F. S., Ozturk, N., Akaydin, G., \& Sener, B. (2012). Profiling of in vitro neurobiological effects and phenolic acids of selected endemic Salvia species. Food Chemistry, 132(3), 1360-1367. http://dx.doi.org/10.1016/j.foodchem.2011.11.119. PMid:29243623.

Ou, S., \& Kwok, K. C. (2004). Ferulic acid: pharmaceutical functions, preparation and applications in foods. Journal of the Science of Food and Agriculture, 84(11), 1261-1269. http://dx.doi.org/10.1002/ jsfa. 1873.

Piluzza, G., \& Bullitta, S. (2011). Correlations between phenolic content and antioxidant properties in twenty-four plant species of traditional ethnoveterinary use in the Mediterranean area. Pharmaceutical Biology, 49(3), 240-247. http://dx.doi.org/10.3109/13880209.2010. 501083. PMid:21323476.

Pokorný, J. (2007). Are natural antioxidants better - and safer - Than synthetic antioxidants? European Journal of Lipid Science and Technology, 109(6), 629-642. http://dx.doi.org/10.1002/ejlt.200700064.

Re, R., Pellegrini, N., Proteggente, A., Pannala, A., Yang, M., \& Rice-Evans, C. (1999). antioxidant activity applying an improved abts radical cation decolorization assay. Free Radical Biology \& Medicine, 26(910), 1231-1237. http://dx.doi.org/10.1016/S0891-5849(98)00315-3. PMid:10381194.

Rota, C., Carraminana, J. J., Burillo, J., \& Herrera, A. (2004). In vitro antimicrobial activity of essential oils from aromatic plants against selected foodborne pathogens. Journal of Food Protection, 67(6), 1252-1256. http://dx.doi.org/10.4315/0362-028X-67.6.1252. PMid:15222560.

Scholey, A. B., Tildesley, N. T. J., Ballard, C. G., Wesnes, K. A., Tasker, A., Perry, E. K., \& Kennedy, D. O. (2008). An extract of Salvia (sage) with anticholinesterase properties improves memory and attention in healthy older volunteers. Psychopharmacology, 198(1), 127-139. http://dx.doi.org/10.1007/s00213-008-1101-3. PMid:18350281.

Şenol, F. S., Orhan, I., Celep, F., Kahraman, A., Doğan, M., Yilmaz, G., \& Şener, B. (2010). Survey of 55 Turkish Salvia taxa for their acetylcholinesterase inhibitory and antioxidant activities. Food Chemistry, 120(1), 34-43. http://dx.doi.org/10.1016/j.foodchem.2009.09.066.

Singleton, V. L., Orthofer, R., \& Lamuela-Raventos, R. M. (1999). Analysis of total phenols and other oxidation substrates and antioxidants by means of folin-ciocalteu reagent. Methods in Enzymology, 299, 152178. http://dx.doi.org/10.1016/S0076-6879(99)99017-1.

Slinkard, K., \& Singleton, V. L. (1977). Total phenol analyses: automation and comparison with manual methods. American Journal of Enology and Viticulture, 28, 49-55.

Šmidling, D., Mitić-Ćulafić, D., Vuković-Gačćić, B., Simić, D., \& Knežević-Vukčević, J. (2008). Evaluation of antiviral activity of fractionated extracts of sage Salvia officinalis L. (Lamiaceae). Archives of Biological Sciences, 60(3), 421-429. http://dx.doi. org/10.2298/ABS0803421S.

Tepe, B., Sokmen, M., Akpulat, H. A., \& Sokmen, A. (2006). Screening of the antioxidant potentials of six Salvia species from Turkey. Food Chemistry, 95(2), 200-204. http://dx.doi.org/10.1016/j. foodchem.2004.12.031. 
Tosun, M., Ercisli, S., Sengul, M., Ozer, H., Polat, T., \& Ozturk, E. (2009). Antioxidant Properties and total phenolic content of eight Salvia species from Turkey. Biological Research, 42(2), 175-181. http:// dx.doi.org/10.4067/S0716-97602009000200005. PMid:19746262.

Villa, C., Trucchi, B., Bertoli, A., Pistelli, L., Parodi, A., Bassi, A. M., \& Ruffoni, B. (2009). Salvia somalensis essential oil as a potential cosmetic ingredient: Solvent-free microwave extraction, hydrodistillation, GC-MS analysis, odour evaluation and in vitro cytotoxicity assays. International Journal of Cosmetic Science, 31(1), 55-61. http://dx.doi.org/10.1111/j.1468-2494.2008.00480.x. PMid:19134128.

Young, I. S., \& Woodside, J. V. (2001). Antioxidants in health and disease. Journal of Clinical Pathology, 54(3), 176-186. http://dx.doi. org/10.1136/jcp.54.3.176. PMid:11253127. 